Wayne State University

DigitalCommons@WayneState

Center for Self-Determination and Transition

College of Education

$1-1-2004$

\title{
Implementation of Self-Determination Activities and Student Participation in IEPs
}

Christine Mason

Cessi, Inc.

Sharon Field

Wayne State University, sharon.field@wayne.edu

Shlomo Sawilowsky

Wayne State University

\section{Recommended Citation}

Mason, C., Field, S., \& Sawilowsky, S. (2004). Implementation of self-determination activities and student participation in IEPs. Exceptional Children, 70(4), 441-451

Available at: http://digitalcommons.wayne.edu/csdt/2 


\section{Implementation of Self-Determination Activities and Student Participation in IEPs}

\section{CHRISTINE MASON}

Cessi, Inc.

\section{SHARON FIELD}

SHLOMO SAWILOWSKY

Wayne State University

ABstract: The Council for Exceptional Children conducted an online Web survey to obtain information on the instructional practices and attitudes of educators as they relate to self-determination and student involvement in the individualized education program (IEP) process. We obtained 523 usable responses from teachers, administrators, and related services professionals. Although respondents highly valued both student involvement in IEPs and self-determination skills, only $8 \%$ were satisfied with the approach they were using to teach self-determination. Only $34 \%$ were satisfied with the level of student involvement in IEP meetings. Implications include the need for longitudinal research and technical assistance, targeting administrators, general educators, and special educators beginning in the elementary grades, to improve the capacity of schools to deliver self-determination instruction.

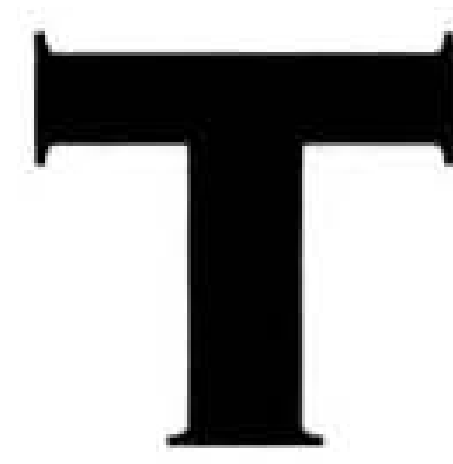

he Individuals with Disabilities Education Act (IDEA) Amendments of 1997 (Public Law 10517) required that children and youth with disabilities ages 14 to 16 be invited to participate in meetings where their individualized education programs (IEPs) are discussed, and that decisions be based on the students' interests and preferences (34 C.F.R. 300.344 (b) (1) and 300.29). Such involvement in transition and IEPs has been strongly encouraged by individuals with disabilities, advocates, researchers, and teachers (Agran, Snow, \&
Swaner, 1999; Johnson \& Emanuel, 2000; National Council on Disability, 2000; Ward, 1988). Research results from the past two decades suggest that youth who are involved in their IEP development or related educational goal setting and planning are more likely to (a) achieve their goals (e.g., Kennedy \& Haring, 1993; Perlmutter \& Monty, 1977; Powers et al., 2001; Realon, Favell, \& Lowerre, 1990; Van Reusen, Deshler, \& Schumaker, 1989), (b) improve their academic skills (Schunk, 1985), (c) develop important selfadvocacy and communication skills (Mason, McGahee-Kovac, Johnson, \& Stillerman, 2002), (d) 
graduate from high school (Benz, Lindstrom, \& Yovanoff, 2000), and (e) gain better employment and quality of life as adults (Furney \& Salembier, 2000; Halpern, Yovanoff, Doren, \& Benz, 1995; Wehmeyer, Agran, \& Hughes, 2000). Related research indicated that individuals with high scores on measures of self-determination were more likely to be employed and obtain higher wages 1 year after graduation than those with low selfdetermination scores (Wehmeyer \& Schwartz, 1997). There is also evidence of a link between high levels of self-determination and student achievement (Houchins, 1998) and grade point average (Sarver, 2000). Although the results from these latter two studies were positioned as preliminary, the general trend indicates that outcomes for youth are strengthened by their involvement in the IEP process and self-determination activities.

Despite the IDEA requirements, research results, teacher perceptions, and strong encouragement from disabilities rights advocates, many youth have been left out of IEP and selfdetermination activities. For example, $31 \%$ of the teachers in a 1998 survey reported that they wrote no self-determination goals, and $41 \%$ indicated that they did not have sufficient training or information on teaching self-determination (Wehmeyer \& Schwartz, 1998). With regard to student participation in IEP meetings, research published since 1994 revealed that only $48 \%$ to $64 \%$ of adolescents studied attended their IEP meetings (deFur, Getzel, \& Kregel, 1994; Grigal, Test, Beattie, \& Wood, 1997; Trach \& Shelden, 2000). These results are consistent with a review of national transition project outcomes by Williams and O'Leary (2000). Williams and O'Leary found that approximately one third of the states were not in compliance with the requirement to invite students to their IEP meetings when transition issues were to be discussed. Furthermore, 26\% of the states were not in compliance in ensuring that the interests and preferences of students would be considered in the development of the IEP.

According to Johnson and Sharpe (2000), more youth today are attending their IEP transition meetings than in previous years. In their survey, completed by 548 local special education administrators representing all 50 states, $82 \%$ of the administrators indicated that students are participating in their IEP transition meetings. Although this is a positive trend, from a research to practice perspective, student attendance at IEP meetings is not the desired outcome of the IDEA transition mandate. Leaders in the field of special education have advocated for involving students in the IEP process in meaningful ways, including ensuring that students actively participate in the IEP process. Active participation may include helping with goal setting, self-advocacy, and selfregulation or self-monitoring. According to Johnson and Sharpe's survey, administrators identified strategies for including students in the IEP process such as (a) interviewing or talking with them about their goals $(89 \%)$, (b) offering a verbal invitation to the meeting (87\%), (c) engaging students in discussion during the IEP meeting $(85 \%)$, and (d) promoting self-determination goals in instructional programs (64\%).

Although student attendance at the IEP meeting is rising, active participation by the student in IEP meetings is often minimal. In the Johnson and Sharpe (2000) survey, administrators indicated that often teachers just used information from student assessments $(79 \%)$, or represented the student's views at the IEP meeting $(68 \%)$. The administrators reported that the least practiced strategy was a student-led meeting (8\%).

A series of educational initiatives has provided funding to develop materials and strategies for enhanced youth self-determination, including involvement in the IEP process. These initiatives included programs that help students develop self-determination related knowledge and skills such as self-awareness, decision making, goal setting and attainment, assertive communication, negotiation, conflict resolution, and reflection. In addition, several curricula have been developed

Despite the IDEA requirements, research results, teacher perceptions, and strong encouragement from disabilities rights advocates, many youth have been left out of IEP and self-determination activities. 
specifically to facilitate active student involvement in the IEP process (e.g., Martin, Huber-Marshall, Maxson, Jerman, \& Miller, 1996; Van Reusen, Bos, Schumaker, \& Deshler, 1994; Wehmeyer \& Kelchner, 1997). The Web page for the SelfDetermination Synthesis Project at the University of North Carolina at Charlotte (http://www.uncc. edu/sdsp) contains a comprehensive listing of these materials.

Given the concern with the importance of student involvement in IEP activities and student self-determination, we were interested in learning more about actual classroom practices and teacher perceptions related to these two areas. We used a survey to obtain information from educators regarding their perceptions of student involvement in IEPs and student self-determination

\section{METHOD}

We conducted an online survey over a 6-week period on the Council for Exceptional Children's (CEC's) Web site (www.cec.sped.org). On CEC's home page, we posted an announcement of the survey and included related incentives (e.g., books, CEC products from CEC's catalog, and an automatic entry into a drawing for one pass to the national CEC convention or a regional seminar). The survey was also distributed via e-mail to a segment of CEC's membership.

\section{INSTRUMENT}

The survey contained four sections: (a) student involvement in IEPs (36 items), (b) selfdetermination activities (12 items), (c) demographic data, and (d) open-ended comments. Survey items addressed the respondent's (a) perceptions of the importance of student involvement in IEPs and self-determination instruction, (b) satisfaction with the IEP process and selfdetermination, (c) involvement of students with IEP meetings, and (d) current instruction regarding self-determination. The survey was designed to be completed in 5 to $10 \mathrm{~min}$. Item format included a mixture of open-ended responses, Likert rankings, and opportunities to "check all that apply."

\section{INSTRUMENT RELIABILITY}

Cronbach's alpha, a measure of internal consistency reliability, was .75 for the IEP process por- tion of the survey (36 items). Note that Cronbach's alpha must be corrected for test length to be interpreted properly. Therefore, the SpearmanBrown prophecy formula was used to project a corrected internal consistency of .8 for 48 items. The internal consistency reliability for the selfdetermination portion of the survey (12 items) was .63. The Spearman-Brown projection of internal consistency for a full survey-length instrument on this subscale was .87 .

\section{RESPONDENTS}

We obtained 523 usable responses to the survey. Geographic representation was obtained for all 50 states in approximately equal proportions. Approximately $2.3 \%$ of the responses were received from Australia, Bahamas, Canada, and Kenya. A one-way analysis of variance test conducted at the nominal $(\alpha=0.05)$ level indicated there were no statistically significant differences in terms of responses to the IEP process or student selfdetermination based on geographic location.

The respondents included special education teachers $(77 \%)$, general education teachers $(12 \%)$, administrators $(8 \%)$, related service professionals $(3 \%)$, teacher education students $(1 \%)$, and staff at institutions of higher education (1\%). Most of the teachers taught at the elementary school $(22 \%)$, middle school $(22 \%)$, or high school (25\%) level. Other respondents taught mixed grades and ages (16\%), preschool $(4 \%)$, or post high school $(1 \%)$. Respondents had an average of $12(\mathrm{Mdn}=10)$ years of experience in education. Teachers were responsible for an average of 24 (1.3) IEPs per year $(\mathrm{Mdn}=16)$.

\section{RES U LTS}

Most respondents reported that although selfdetermination activities, including studentinvolvement in IEPs, were very important, they were dissatisfied with both current instructional activities and their preparation to provide instruction in these skills. Moreover, respondents described student involvement in IEP meetings as minimal. A more detailed description of these results, as well as data for subgroups of respondents (i.e., administrators vs. teachers; elementary vs. secondary teachers) follows. 


\begin{tabular}{lrc} 
& Important & Very Important \\
\hline Importance of self-determination skills & $100 \%$ & $86 \%$ \\
Importance of student involvement in IEP meetings & $95 \%$ & $70 \%$
\end{tabular}

TABLE 2

Student Involvement in the IEP Process Previous Year

\begin{tabular}{lccc}
\hline & Not Involved & Somewhat & Very Involved \\
\hline Student involvement previous year & $32 \%$ & $58 \%$ & $10 \%$
\end{tabular}

IMPORTANCE OF SELF-DETERMINATION AND STUDENT INVOLVEMENT IN THE IEP

Self-determination skills and IEP involvement were both deemed to be important by respondents (see Table 1).

According to respondents, students who were more involved in their IEP process knew more about their accommodations $(71 \%)$ and disability $(60 \%)$ and were more assertive in asking for accommodations (59\%).

There was a subtle but statistically significant correlation between how involved students were in the IEP process and the respondents' ratings regarding the importance of selfdetermination activities $(r=.11, p<.01)$. Also, respondents who reported that they taught selfdetermination skills tended to rate self-determination as being more important $(r=.13, p<.01)$. The statistical significance of these low correlations may also be explained by the large sample size.

\section{STUDENT INVOLVEMENT IN IEPS}

Most of the respondents described students as "only somewhat involved with their IEP process" during the previous year (see Table 2).

Moreover, when asked to select statements describing the type of student involvement in the IEP process this year, the most prevalent response was that "students attended the IEP meeting, but were not that involved." (see Table 3).

\section{STUDENT PREPARATION FOR IEP INVOLVEMENT}

According to respondents, in preparation for the IEP meeting, students were most likely to determine their accommodations and goals (see Table 4).

Ninety-two percent reported that the average amount of time spent preparing for the IEP meeting with the student was 1 to $3 \mathrm{hr}$. The most common response to the question about when planning occurred was "in a special education class" $(29 \%)$.

\section{INSTRUCTION IN SELF-DETERMINATION}

Most respondents identified the approach to teaching self-determination skills as informal $(70 \%)$ with only limited instruction $(41 \%)$. However, approximately two thirds of the respondents reported that they taught the related skills of self-management and goal setting/management to their students. Only 39 respondents $(7 \%)$ answered the question regarding the district's overall plan to teach self-determination. The majority of these respondents indicated that their districts did not have a districtwide plan for teaching selfdetermination and self-advocacy.

\section{SATISFACTION}

As predicted in the literature review, educators were more dissatisfied with the level of student involvement in their IEPs than satisfied $(45 \%$ were somewhat to very dissatisfied; $34 \%$ were somewhat to very satisfied). Similarly, respondents ex- 
Students attended IEP meeting, but not that involved 46

Students most involved in transition planning

Students invited teachers and parents to the meeting or discussed the IEP with them prior to the meeting Students provided input prior to the meeting

Students chaired or co-chaired the meeting

\section{TABLE 4}

Student Preparation for IEP Meeting

\begin{tabular}{lc}
\hline Students helped to determine accommodations & $\begin{array}{c}\text { Percentage of } \\
\text { Respondents }\end{array}$ \\
Students helped to determine goals & 36 \\
Students received instruction about the IEPs prior to the meeting & 33 \\
Students rehearsed prior to the meeting & 28 \\
Students used person-centered planning & 9 \\
Students used scripts during the meeting & 8 \\
\hline
\end{tabular}

pressed dissatisfaction with their district's approach to self-determination $(42 \%$ were somewhat to very dissatisfied; $8 \%$ were somewhat to very satisfied). They were more satisfied with their districts' general approach to IEPs than they were with either student involvement in IEPs or with their district's approach to self-determination (65\% were somewhat to very satisfied; $23 \%$ were somewhat to very dissatisfied).

This discrepancy can be explained by examining the difference in the two questions posed. One question focused on the broader issue of the districts' overall approach to the IEP (which encompasses a range of components such as parent involvement, scheduling, procedures), and the other question focused solely on one component of the IEP process (student involvement). The degree of satisfaction with the IEP process was slightly correlated with respondents' perceptions of how involved students were in the IEP process, with respondents reporting higher levels of student involvement tending to be more satisfied $(r$ $=.17, p<.01)$.

\section{PREPARATION FOR TEACHING SELF- DETERMINATION AND IEP INVOLVEMENT}

Fifty percent of the respondents indicated that they could use more training in teaching selfdetermination/self-advocacy. Only $22 \%$ indicated that they were very prepared to teach these skills.

\section{DIFFERENCES BETWEEN ELEMENTARY AND SECONDARY TEACHERS}

On items where there were statistically significant differences between secondary and elementary teachers, secondary teachers were consistently more likely to respond positively to questions related to student involvement in the IEP and selfdetermination. The data related to the differences in responses by elementary and secondary teachers are compiled in Table 5. Secondary teachers reported higher levels of student involvement in the IEP $(M=.96$ vs. .47 ; scale is $0=$ not involved, 2 = very involved). They also rated the importance of student involvement in the IEP more highly than were elementary-level teachers $(M=$ 2.77 vs. 2.44 ; scale is $0=$ not important, $3=$ very important). Secondary teachers were more likely to state that they were prepared to teach self-determination skills than were elementary teachers $(M=1.75$ vs. 1.45 ; scale is $0=$ not important-no preparation needed, 3 = very prepared). Secondary teachers were also more likely than elementary teachers to state that they provide (a) self-determination instruction through the use of a formal curriculum ( $M=.24$ vs. .14$)$, (b) systematic instruction in self-determination $(M=$ .31 vs. .20$)$, (c) informal self-determination instruction $(M=.78$ vs. .65$)$, and (d) instruction to help students learn to set and manage goals $(M=$ 
TABLE 5

\begin{tabular}{|c|c|c|c|c|c|c|}
\hline \multirow[t]{2}{*}{ Item } & \multicolumn{2}{|c|}{ Elementary } & \multicolumn{2}{|c|}{ Secondary } & \multirow{2}{*}{$\begin{array}{c}\text { Difference } \\
\text { T }\end{array}$} & \multirow{2}{*}{$\begin{array}{c}\text { Effect Size } \\
\text { ES }\end{array}$} \\
\hline & $\mathrm{M}$ & SD & M & SD & & \\
\hline $\begin{array}{l}\text { Level of student involvement with } \\
\text { IEP }\end{array}$ & .47 & & .96 & .55 & $-7.56^{\circ}$ & -.85 \\
\hline Importance of student participation & 2.44 & .70 & 2.77 & .51 & $-4.75^{\bullet}$ & -.56 \\
\hline $\begin{array}{l}\text { Prepared to teach self-determination } \\
\text { skills }\end{array}$ & 1.45 & .72 & 1.75 & .80 & $-3.43^{\circ}$ & -.39 \\
\hline Teach students to set/manage goals & .55 & 50 & .76 & .43 & $-3.94^{*}$ & -.45 \\
\hline $\begin{array}{l}\text { Provides informal self-determination } \\
\text { instruction }\end{array}$ & .65 & .48 & .78 & .42 & $-2.51^{\bullet}$ & -.28 \\
\hline $\begin{array}{l}\text { Use formal self-determination } \\
\text { curriculum }\end{array}$ & .14 & .35 & .24 & .43 & $-2.20^{*}$ & -.25 \\
\hline $\begin{array}{l}\text { Provide systematic self- } \\
\text { determination instruction }\end{array}$ & .20 & .40 & .31 & .46 & $-2.19^{*}$ & -.25 \\
\hline
\end{tabular}

.76 vs. .55 ; with the scale for these four items being $0=$ no and $1=$ yes).

\section{DIFFERENCES BETWEEN TEACHERS AND ADMINISTRATORS}

Several differences were found between the perceptions of teachers and administrators related to student involvement in IEP meetings and selfdetermination. These differences are compiled in Table 6. Administrators responded more favorably for all questions where statistically significant differences were found between the two groups (See Table 6).

Administrators reported higher mean responses than teachers for student involvement in IEPs $(M=1.03$ vs. .77). In a section where respondents were asked to check all that apply (e.g., 0 = does not apply, 1 = applies), administrators reported higher mean number of times the following applied: (a) engaging students in specific activities related to their IEPs, including communicating with others about the IEP $(M=.18$ vs. $.07)$; (b) chairing the IEP meeting ( $M=.12$ vs. $.03)$; (c) helping to determine IEP goals $(M=.50$ vs. .33); (d) helping to determine necessary acoommodations ( $M=.47$ vs. .37); and (e) involving students primarily with transition planning. $(M=.56$ vs. .27$)$.
The positive perceptions of administrators regarding student involvement in the IEP process were echoed in the responses of administrators to statements about self-determination instruction. Administrators were more likely than teachers to state that their districts provide informal instruction for self-determination $(M=.50$ vs. .24 ; with $0=$ no and $1=y e s)$. They also were more likely to indicate that their districts have an overall district plan for teaching self-determination $(M=2.33$ vs. .33 ; with $0=$ no, $2=$ yes) and systematic instruction each year for $\mathrm{K}$ through 12 . (The response to the question regarding an overall plan for teaching self-determination must be interpreted with caution because very few teachers or administrators responded to this item.) Administrators were also more likely than teachers to indicate that the district was prepared to teach self-determination skills $(M=2.06$ vs. $1.67 ; 0=$ not important, 3 = very prepared).

Differences were also found between teachers and administrators in terms of their relative satisfaction with the IEP process, with administrators tending to be somewhat more satisfied $(M$ $=2.82$ vs. $2.41 ; 0=$ very dissatisfied, $4=$ very sat isfied). Although there was no statistically significant difference in mean response between the two 


\begin{tabular}{|c|c|c|c|c|c|c|}
\hline \multirow[t]{2}{*}{ litem } & \multicolumn{2}{|c|}{ Teachers } & \multicolumn{2}{|c|}{ Administrators } & \multirow{2}{*}{$\begin{array}{c}\text { Differmate } \\
\mathrm{t}\end{array}$} & \multirow{2}{*}{$\begin{array}{c}\text { Effect Sizes } \\
\text { ES }\end{array}$} \\
\hline & M & SD & M & SD & & \\
\hline Satisfaction with general IEP process & 2.41 & 1.10 & 2.82 & .97 & $-2.12^{*}$ & -38 \\
\hline Number of IEPs last year & 22.97 & 26.46 & 39.40 & 55.22 & $-3.15^{*}$ & .57 \\
\hline Level of student involvement wth IEP & .77 & .63 & 1.03 & .58 & $-2.31^{\circ}$ & .41 \\
\hline Level of student responsibility for communicating with others re. IEP & .07 & .26 & .18 & 39 & $.2 .22^{\circ}$ & -38 \\
\hline Students chaired IEP meeting & .03 & .18 & .12 & 33 & $-2.40^{\circ}$ & .42 \\
\hline Students wete most involved with transition plans & .27 & .66 & .56 & 1.15 & $.3 .53^{\circ}$ & .65 \\
\hline Students helped determine IEP goals & 33 & .47 & .50 & 51 & $.201^{\circ}$ & .36 \\
\hline Students determined accommodations for IEP meetings & 37 & .48 & .47 & .51 & $.2 .25^{\prime}$ & .21 \\
\hline District provides informal instruction for self-determination & .24 & .43 & .50 & .51 & $.3 .36^{\circ}$ & .63 \\
\hline Preparedness for teaching self-determination & 1.67 & .80 & 2.06 & .90 & $.2 .72^{\circ}$ & .50 \\
\hline Existence of district plan for self-determination & .33 & .66 & 2.33 & 1.15 & $-4.70^{\circ}$ & -2.34 \\
\hline
\end{tabular}

$$
p<0.05
$$

groups (administrators were more satisfied than teachers), both groups were relatively dissatisfied with student involvement in IEPs $(M=1.9$ vs. 1.7 , using same scale as the previous item).

\section{DISCUSSION}

The results of this study confirm that special educators place a very high value on both selfdetermination and student involvement in the IEP process. Moreover, significant differences were evident between middle/high school staff and preschool/elementary staff, with a tendency toward more instruction and greater satisfaction with self-determination and student participation in IEP processes at the secondary level. Teachers who were the most involved with student participation in the IEP tended to express the greatest satisfaction.

Our results showed that instruction regarding self-determination tended to be unsystematic and informal and that districtwide leadership was rare. Teachers expressed that they were somewhat more prepared to teach self-determination skills than to instruct students about their participation in the IEP process. They also expressed considerable interest in receiving more training in both of these areas.

One of the findings that may have significant implications for future work in the area of self-determination and student participation in IEP processes is that students were not very in- volved in their IEP processes (i.e., students were much more likely to attend their meetings but not otherwise participate). According to the survey respondents, when students are involved in IEP meetings, they tend to simply attend and play a passive role rather than actively participating in the process. Only $28 \%$ of the respondents indicated that students received instruction about IEPs prior to the IEP meeting, and most student preparation occurred in as little as 1 to $3 \mathrm{hr}$. Student involvement in IEP meetings is an important self-determination/self-advocacy skill that can enhance achievement of IEP goals and prepare students for later meetings with vocational rehabilitation counselors, postsecondary instructors, and employers. To enhance this involvement, ways to help teachers meet with students, plan together for their participation in IEP meetings, monitor student progress in planning for that meeting, and ensure that students follow up a after the meetings are needed.

Although they rated instruction in selfdetermination as highly important, most respondents indicated that their use of it was informal and unsystematic. The impact of such practice is unclear. Because research on the effectiveness of self-determination has been conducted with several published materials using systematic procedures that are a part of a curriculum that has been field-tested, the impact of more informal curric- 
ula approaches needs to be investigated. From our current knowledge base, it appears that time may be better spent using research-validated procedures (i.e., formal, systematic curricula).

According to our results, administrators and teachers generally disagreed about the extent of student involvement in IEP and selfdetermination activities, with administrators tending to report greater levels of involvement and a stronger focus in their programs on self-determination. Reasons for the discrepancies are unclear, but certainly suggest that progress reports on implementation of self-determination in school systems should not rely solely on reports from administrators.

\section{IMPLICATIONS FOR PRACTICE}

Teachers indicated that they would benefit from additional training and information regarding curricula in order to support greater student involvement in IEP and self-determination activities. Moreover, it appears that elementary teachers are in greater need of such training than secondary teachers. Both preservice and inservice training could be useful to teachers and teacher candidates. Researchers, university instructors, and school district consultants need to explore ways to enhance teacher knowledge and skills both during initial preparation and through district in-service professional development practices.

Using widespread, systematic technical assistance (TA) that has been proven to be effective to improve teacher implementation of selfdetermination activities is recommended (Test, et al. 2004). Given the many pressures teachers and administrators face today, particularly in reference to high-stakes assessment and implementation of No Child Left Behind, it is important that researchers address the impact of systematic implementation of self-determination activities in schools across grade levels within districts. Given our knowledge about levels of proficiency and the relationship to skill use, it is important that teachers know how to instruct students to ensure they reach mastery of self-determination skills, including how to determine appropriate criteria for mastery. A TA, research-to-practice agenda may be particularly important in helping educators identify how to provide sufficiently intense instruction in self-determination skills. Because research continues to identify the importance of self-determination skills and the particular lack of implementation at the elementary level, researchers and practitioners may want to pair self-determination activities with other elementary school initiatives, such as initiatives to increase literacy and implement effective prereferral interventions. It is critical that a substantial number of districts be targeted for intensive, longitudinal interventions. Data obtained from these

According to our results, administrators and teachers generally disagreed about the extent of student involvement in IEP and self-determination activities, with administrators tending to report greater levels of involvement and a stronger focus in their programs on self-determination.

intensive districtwide interventions could be essential to increasing the likelihood of effective implementation of self-determination activities and providing the appropriate guidance to bring best practices to scale across the nation.

As the implementation of selfdetermination activities is undertaken on a more intensive scale, practitioners will need to make decisions regarding student involvement in IEPs. The IEP is an excellent vehicle for helping students learn and express self-determination skills. However, it is important that other ways are found to help students focus on goal setting and attainment, for these remain important, with or without the context of the IEP meeting. Depending on the results of IDEA Reauthorization, the IEP may or may not continue to be a viable target for annual preparation and practice in self-determination. Student involvement in goal setting should include both student understanding and involvement with long- and short-term planning. Long-term planning could be accomplished through activities that focus on students' visions for their own future as well as transition planning. 
Short-term planning could be addressed through student goal setting for specific content area subjects, and specific time periods that correspond to important benchmarks within the school year. For example, students could be taught to set and measure progress toward meeting quarterly goals.

In implementing self-determination activities, logistical concerns regarding where and when to provide instruction must be resolved. Because students with disabilities receive instruction in the general education curriculum primarily in the general education classroom, adequate attention must be given to ensure that general educators and administrators understand and value selfdetermination activities. This implies that TA must target these groups and that it must begin with an adequate needs assessment of the interests and priorities of these stakeholders. Some previous self-determination efforts have targeted general education as well as special education populations (e.g., Hoffman \& Field, 1996). Therefore, it seems feasible to consider the relative value of self-determination activities for all students and then consider how to differentiate self-determination instruction for students with varying degrees and types of disabilities/needs. If teachers and administrators found self-determination skills useful in raising the achievement of all students, perhaps they would place a higher priority on using classroom instructional time for teaching these skills.

Our recommendation, based on knowledge to date, is to undertake large-scale TA projects that target administrators and general and special education teachers. These TA projects should be districtwide and of sufficient duration to provide concrete answers to logistical questions. Discussions with districts that have implemented substantial self-determination programs could provide a valuable resource for these projects. One model for providing such TA includes the following components: (a) collaboration with a nearby university to increase preservice as well as inservice skills, (b) instruction using curricula that have proven to be effective in increasing selfdereminarion skills, and (c) graduated increase in expectations.

Realistically, there will always be a need for some programs to begin at the secondary level, particularly because students with disabilities need to have at least some of these self- determination skills before they leave school. However, if longitudinal evidence is critical, even as districts focus on high school youth, districts need to study the longitudinal effects with students who began implementation in the elementary grades. Districts can then gradually move self-determination programs up the grade levels, so that as the first cohort moves from primary to intermediate grades, and then intermediate to secondary grades, the self-determination curriculum proceeds with the cohort. With this model, use of self-determination would increase in developmental increments.

Our final recommendation for improving practice is to ensure widespread dissemination to key stakeholders. Once we have systematic answers about how to implement large scale reforms supporting self-determination activities, this information should be shared widely through a variety of forums and dissemination routes (e.g., Web-based, articles, site visits, presentations). A targeted TA agenda is necessary to ensure that effective, scientifically based self-determination practices are better understood and implemented. The results to date are so promising that this agenda should be implemented as quickly as possible on a scale large enough to allow for the impact of adequately funded and supported programs to be evaluated. If this is accomplished, then perhaps we will no longer find teachers who highly value self-determination skills but feel unqualified to provide instruction. Moreover, if the proposed TA agenda were adopted, perhaps teachers would report that they found sufficient administrative support and that they no longer had logistical concerns about where and when to implement self-determination instruction.

\section{REFERENCES}

Agran, M., Snow, K., \& Swaner, J. (1999). Teacher perceptions of self-determination: Benefits, characteristics, and strategies. Education and Training in Mental Retardation and Developmental Disabilities, 34, 293-301.

Benz, M., Lindstrom, L., \& Yovanoff, P. (2000). Improving graduation and employment outcomes of students with disabilities: Predictive factors and student perspectives. Exceptional Children, 66, 509-529. 
de Fur, S., Getzel, E. E., \& Kregel, J. (1994). Individual transition plans: A work in progress. Journal of $\mathrm{Vo}$ cational Rehabilitation, 4, 139-145.

Furney, K. S., \& Salembier, G. (2000). Rhetoric and reality: A review of the literature on parent and student participation in the IEP and transition planning process. In D. R. Johnson \& E. J. Emanuel (Eds.), Issues influencing the future of transition programs and services in the United States (pp. 11-126). Minneapolis, MN: University of Minnesota.

Grigal, M., Test, D., Beattie, J., \& Wood, W. (1997). An evaluation of transition components of individualized education programs. Exceptional Children, 53, 357-372.

Halpern, A., Yovanoff, P., Doren, B., \& Benz, M. (1995). Predicting participation in postsecondary education for school leavers with disabilities. Exceptional Children, 62, 151-164.

Hoffman, A., \& Field, S. (1996). Promoting selfdetermination through effective curriculum development. Remedial and Special Education, 30(3),134-141.

Houchins, D. E. (1998). The self-determination of youth with and without disabilities who have been adjudicated. Unpublished doctoral dissertation. University of Florida, Gainesville.

Johnson, D. R., \& Emanuel, E. J. (Eds.). (2000). Issues influencing the future of transition programs and services in the United Sattex. Minneapolis, MN: University of Minnesora. Johnson, R. D., \& Sharpe, N. M. (2000). Analysis of local education agency efforts to implement the transition services requirements of IDEA of 1990 . In D. R. Johnson \& E. J. Emanuel (Eds.), Issues influencing the future of transition programs and services in the United States (pp. 31-48). Minneapolis, MN: University of Minnesota.

Kennedy, C. H., \& Haring, T. G. (1993). Teaching choice making during social interactions to students with profound multiple disabilities. Journal of Applied Behavior Analysis, 22(2), 63-76.

Martin, J., Huber-Marshall, L., Maxson, L., Jerman, P., \& Miller, T. L. (1996). The self-directed IEP. Longmont, CO: Sopris-West.

Mason, C., McGahee-Kovac, M.. Johnson, L., \& Stillerman, S. (2002). Implementing student-led IEPs: Student participation and student and teacher reactions. Career Development for Exceptional Individuals, 25, 171-192.

National Council on Disability. (2000). Transition and post-school outcomes for youth with disabilities: Closing the gaps to post-secondary education and employment. Washington, DC: Author.
Perlmutter, L. C., \& Monty, R. A. (1977). The importance of perceived control. Fact or fantasy? American Scientist, 65, 759-765.

Powers, L. E., Turner, A., Westwood, D., Matuszewski, J., Wilson, R., \& Phillips, A. (2001). TAKE CHARGE for the future: A controlled field-test of a model to promote student involvement in transition planning. $\mathrm{Ca}$ reer Development for Exceptional Individuals, 24, 85-104.

Realon, R. E., Favell, J. E., \& Lowerre, A. (1990). The effects of making choices on engagement levels with persons who are profoundly mentally handicapped. Education and Training in Mental Retardation, 25, 248254.

Sarver, M. D. (2000). A study of the relationship between personal and environmental factors bearing on self-determination and the academic success of university students with learning disabilities. Unpublished doctoral dissertation, University of Florida, Gainesville.

Schunk, D. H. (1985). Participation in goal setting: Effects on self-efficacy and skills on learning disabled children. The Journal of Special Education, 19, 307-316.

Test, D., Mason, C., Hughes, C., Konrad, M., Neale, M., \& Wood, W. (2004). Student involvement in individualized education program meetings. Exceptional Children, 70, 437-449.

Trach, J., \& Shelden, D. (2000). Meeting attendance and transition outcomes as reflected in students' individualized education programs. In D. R. Johnson \& E. J. Emanuel (Eds.), Issues influencing the future of transition programs and services in the United States (pp. 127136). Minneapolis, MN: University of Minnesota.

Van Reusen, A. K., \& Bos, C. S. (1994). Facilitating student participation in individualized education programs through motivation strategy instruction. TEACHING Exceptional Children, 60, 466-475.

Van Reusen, A. K., Deshler, D. D., \& Schumaker, J. B. (1989). Effects of a student participation strategy in facilitating the involvement of adolescents with learning disabilities in the individualized educational program planning process. Learning Disabilities: A Multidisciplinary Journal, 1, 23-24.

Ward, M. J. (1988). The many facets of selfdetermination. NICHCY Transition Summary. National Information Center for Children and Youth with Disabilities, 5, 2-3.

Wehmeyer, M., Agran, M., \& Hughes, C. (2000). A national survey of teachers' promotion of selfdetermination and student-directed learning. Journal of Special Education, 34(2), 58-68. 
Wehmeyer, M. L., \& Kelchner, K. (1997). Whose future is it anyway?' A student-directed transition planning program. Silver Spring, MD: The Arc of the United States.

Wehmeyer, M. L., \& Schwartz, M. (1997). Selfdetermination and positive adult outcomes: A followup study of youth with mental retardation or learning disabilities. Exceptional Children, 63, 245-255.

Wehmeyer, M. L., \& Schwartz, M. (1998). The selfdetermination focus of transition goals for students with mental retardation. Career Development for Exceptional Individuals, 21, 75-86.

Williams, J., \& O'Leary, E. (2000). Transition: What we've learned and where we go from here. In D. R. Johnson \& E. J. Emanuel (Eds.), Issues influencing the future of transition programs and services in the United States (pp. 153-158). Minneapolis, MN: University of Minnesota.

\section{ABOUT THE AUTHORS}

CHRISTINE MASON (CEC \#192), Educational Consultant and Senior Research Scientist, Cessi, Inc., Mclean, Virginia. SHARON FIELD (CEC \#1), Professor; and SHLOMO SAWILOWSKY, Professor, Educational Evaluation and Measurement, College of Education, Wayne State University, Detroit, Michigan.

Correspondence concerning this article should be sent to Christine Mason, e-mail: christine.mason4 @cox.net

Manuscript received May 2003; accepted June 2003.

\section{POSITION VACANCY \\ ASSISTANT DIRECTOR OF \\ SPECIAL EDUCATION \\ ADULT AND GRADUATE STUDIES \\ DIVISION}

\section{POSITION DESCRIPTION:}

The Adult and Graduate Studies Division has a position vacancy for an Assistant Director of Special Education. The Assistant Director of Special Education reports to the Dean of the College of Adult and Professional Studies and administers the Special Education Certificate program, delivered via online education, in the College of Adult and Professional Studies (CAPS).

\section{QUALIFICATIONS:}

Indiana Wesleyan University seeks an individual with a strong Christian commitment.

This individual must possess a Master's degree, Doctorate in Special Education preferred; licensed to teach Special Education; 3 years experience in a $\mathrm{K}-12$ school administrative position; 5 years experience in K-12 classroom teaching; excellent interpersonal, written and verbal communication skills; and the ability to conceptualize, design and implement new programs.

\section{SALARY \& BENEFITS:}

This is a full-time, exempt position with a comprehensive benefit package. Salary is established within the appropriate range.

\section{PROCEDURE:}

Applications can be accessed on our website at www.indwes.edu/hr. Send letter of application, current resume, and application to:

\section{Human Resources Indiana Wesleyan University $4201 \mathrm{~S}$. Washington St. \\ Marion, IN 46953 EOE/AA}

POSTED: 02/26/2004.

CLASSIFICATION: 16

Applications received until position filled. 